\title{
Irrigation as Strengthening of Smallholder in the Municipality of Salto do Lontra
}

\author{
Diane Ostroski ${ }^{1}$, Marcio A. Vilas-Boas ${ }^{2}$, Mariângela Pierucinni ${ }^{2}$, Ana Cláudia Guedes Silva ${ }^{1} \&$ Allan Remor ${ }^{1}$ \\ ${ }^{1}$ Graduation Program, Master's in Agricultural Engineering, State University of West Parana, Brazil \\ ${ }^{2}$ Graduation Program, Master's in Engineering of Energy in Agriculture, State University of West Parana, Brazil \\ Correspondence: Diane Ostroski, Graduation Program, Master's in Agricultural Engineering, State University of \\ West Parana, Brazil. E-mail: dianeostroski@gmail.com
}

\author{
Received: May 7, $2019 \quad$ Accepted: June 21, $2019 \quad$ Online Published: August 31, 2019 \\ doi:10.5539/jas.v11n14p161 URL: https://doi.org/10.5539/jas.v11n14p161
}

\begin{abstract}
The irrigation technology for smallholder agriculture is an important instrument to increasing both productivity and income. However for the incorporation of this technology to succeed into small properties, there is a need for interlocution among the different spheres of coordination of these economic agents. In this way, the main objective of this work was to analyze the participation of the institutional and organizational environments of the district of Salto do Lontra, located in the southwestern region of Parana state, in both the dissemination and strengthening of irrigation. This region has the highest concentration of smallholders in the state, hence its relevance. A detailed analysis of the organizational environment was made, in which interviews to the representatives of the organizations werw inserted in the management process of this sector. In order to identify the efficiency of organizations and the accessibility of public credit policies, questionnaires were applied to 35 irrigating smallholders, considering local customs, values and skills. The results demonstrated that the credit policy obtained by the public authority corroborates for the permanence of this economic and social agent in the field. However, organizations work individually, without synchronizing the needs of the category. On the other hand highlighting the universities, which proved to be strong disseminators of irrigation technology locally.
\end{abstract}

Keywords: organizational environment, institutional environment, agricultural credit, university extension

\section{Introduction}

The smallholder agriculture plays a major role in the world food security, as well as it helps the maintenance of millions of direct jobs (FAO, 2014). In Brazil, 4.368.000 rural establishments are family owned, holding about $20 \%$ of the land with approximately $40 \%$ of the national production and generating 12.5 million direct jobs, a fact that praises its importance (IBGE, 2006).

Parana which is located in the southern region of the country, is among the states with significant representation of technified and of transition smallholder agriculture. The state is the $2^{\circ}$ largest grain producer in Brazil, accounting for approximately $22 \%$ of the national production (SEAB, 2018). Also, its economy is strong in the milk production chain, accounting for $11.34 \%$ of total production, the southwest region of the state being the largest producer with 1.114 billion liters/year (IBGE, 2017).

In Parana, from the 371.051 agricultural establishments, $81.63 \%$ are represented by smallholder agriculture. The category occupies a total area of $27.8 \%$ with participation in the Gross Value of Production (VBP) in the order of $43 \%$, besides occupying $70 \%$ of the labor. The southwest region of the state is in first place with $88.9 \%$ of its properties being formed by smallholder agriculture (IBGE, 2006). The technological appropriation becomes a differential in the state, providing the insertion in the market in a competitive and consistent way.

By integrating itself with capital, family agriculture combines its survival with the capacity to increase its participation in an increasingly competitive market. This reality transformation is supported by the competence of smallholders and the appropriation of new technologies, such as the use of irrigation systems.

Irrigation becomes relevant to the Brazilian family agriculture by directly interfering with food productivity, increasing up to 3.5 times production in rainfed areas or climatic inclement weather. The financial return may be 7 times higher (MDA, 2015). A technology that can help improve the life quality of this group of rural workers. 
The relationship between smallholder agriculture and irrigation technology has been studied worldwide. The emphasis of the studies focuses on the efficient use of water by irrigation (Kooij, Kuper, Fraiture, Lankford, \& Zwarteveen, 2017; Cunha \& Rocha, 2015; Mwangi \& Crewettb, 2018; Khor \& Feike, 2017; Tijani, Obayelu, Sobowale, \& Olatunji, 2015; Beekman \& Bolding, 2014; Hagos \& Mamob, 2014; Giordano \& Fraiture, 2014). However, few articles address the importance of institutional and organizational environments as a tool for irrigation strengthening in smallholder agriculture.

Organizations can be disseminators of irrigation technology among family farmers. With joint effort, they are able to inform, empower and direct the producer regarding the use of this technology in an efficient and profitable way.

The trust and representativeness of the organizations to the family farmer corroborate in the perception of the intrinsic problems to each property, contributing in the uncertainties and difficulties reduction, detected in the implantation and management of the irrigation locally. They are considered the link between the family farmer and the institutional environment, governed by laws and public policies aimed at the sector, especially the rural credit.

Thus, this objective is to identify the participation of the organizational and institutional environments in the dissemination process and strengthening of irrigation in family agriculture. The field study will take place in the municipality of Salto do Lontra, southwest of Paraná, as it is the region with the largest number of smallholders in the state.

This empirical approach can contribute to verify the importance of environments in the process of strengthening family irrigation agriculture in different regions of the country, aiming at improving the quality of life of the farmers and the sustainability of the developed production.

\section{Method}

\subsection{Local Characterization}

The study was carried out in the district of Salto do Lontra, southwest of Parana. In the last decades, the irrigation technology has assumed relevant participation in the strengthening of the smallholder agriculture of Parana. There has been a $167 \%$ increase in the nationally irrigated area in the last 20 years, while the South region hás grown by $73 \%$ and the Parana state, with a growth of $232.2 \%$ (Table 1 ).

Table 1. Panorama of irrigation in Brazil, southern region and Parana state, according to the last agricultural censuses

\begin{tabular}{|c|c|c|c|c|c|c|c|c|c|}
\hline & \multicolumn{3}{|c|}{ Establishments number (total) } & \multicolumn{3}{|c|}{ Establishments number with irrigation } & \multicolumn{3}{|c|}{ Irrigated area (ha) } \\
\hline & $95 / 96$ & 2006 & 2017 & $95 / 96$ & 2006 & 2017 & $95 / 96$ & 2006 & 2017 \\
\hline Brazil & 4.859 .865 & 5.175 .636 & 4.993 .578 & 129.476 & 331.990 & 505.503 & 2.590 .000 & 4.545 .534 & 6.902 .960 \\
\hline Sul & 1.003 .180 & 1.006 .203 & 850.684 & 53.803 & 50.847 & 59.370 & 1.003 .180 & 1.238 .812 & 1.731 .517 \\
\hline Paraná & 369.875 & 371.063 & 304.110 & 13.518 & 12.656 & 16.659 & 46.890 & 105.455 & 155.782 \\
\hline
\end{tabular}

Note. DU: Censures Agricultural 95/96, 2006 and 2017.

Adapted of Loiola and Souza (2001).

The district of Salto do Lontra (Figure 1) has a population of 14.713 inhabitants and a total area of approximately $313 \mathrm{Km}^{2}$ (IPARDES, 2014). The city is bathed by the rivers Otter, Jaracatiá, Mombuco and Cotejipe. The climate of the region is characterized as Humid Subtropical Climate (Cfa), with na average precipitation of $1.900 \mathrm{~mm}$, Evapotranspiration of $1.000 \mathrm{~mm}$ and average temperature of $18.5^{\circ} \mathrm{C}$ (Caviglionli et al., 2002). 

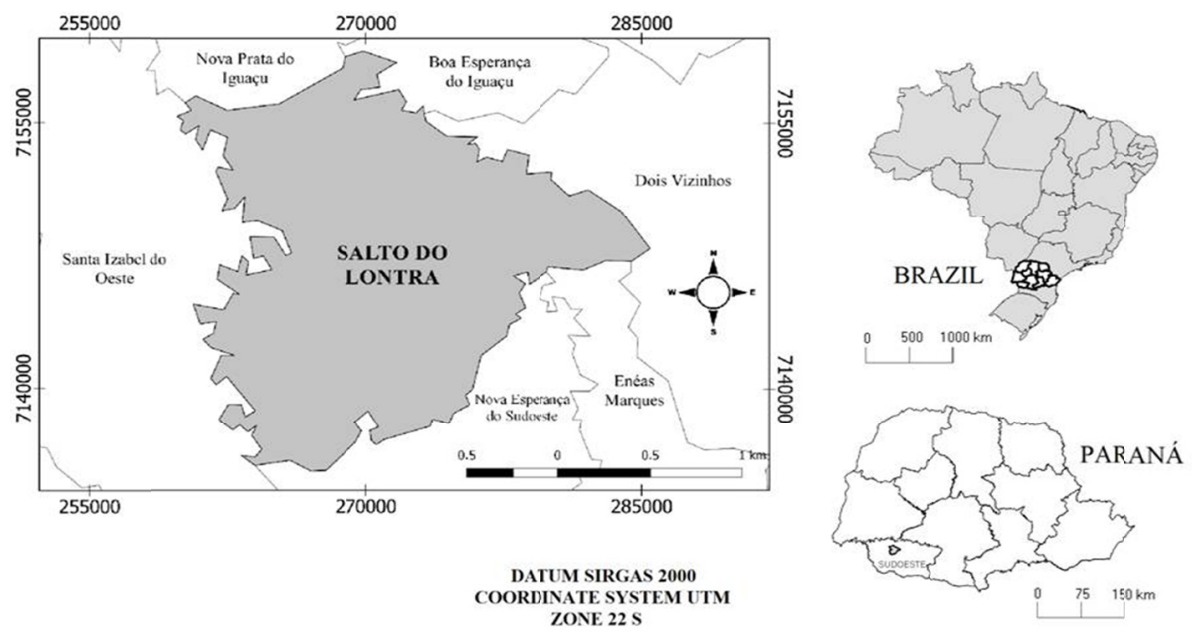

Figure 1. Location map of the district Salto do Lontra - PR

Its economy is centered on family agribusiness with 1.410 rural properties, of which 927 are smallholders, as well as dozens of family and industrial agribusinesses (IBGE, 2017). It has a GDP per capita of R $\$ 19.690 .00$ and a gross production value of $\mathrm{R} \$ 350$ million (IPARDES, 2017).

Several studies were carried out in the district Salto do Lontra. This is due to the extension work developed by the Irrigation and Fertirrigation Laboratory of the Agricultural Engineering course from State University of West Parana, which realized the possibility and necessity of bringing information and knowledge about irrigation technology to a group of distant smallholders from university centers.

Through a larger project under the title: Quality control of irrigation in rural units of family base, aiming the conservation of water resources in the district of Salto do Lontra, drip irrigation kits were distributed. This served to stimulate local smallholder in the use of technology.

The project started in 2008, when the municipality had 67 irrigating family farmers, reaching 103 in 2012. Currently, there are only 62 family farmers irrigating in the municipality, a large part of the project started by the university in 2008.

The monitoring of this producers group sought to quantify several variables, such as: the uniformity of the irrigation system, the hydraulic load in the application of water and fertilizer, the evapotranspiration, the water quality used to irrigate and the socioeconomic analysis of this project.

\subsection{Data Collection}

The population of irrigating smallholders in the municipality of Salto do Lontra is 63 with an area of up to 100 hectares. The sample used in this scientific research was of 35 irrigating family farmers, being non-probabilistic. The criteria for selection of the sample were: accessibility, time and available resources.

To obtain the variables listed, questionnaires were applied with semi-structured questions divided into quali and quantittavas for the group of 35 irrigation smallholders from March 20, to May 01, 2019. Access to the properties was done by own vehicle. The addresses were provided by the Technical Assistance and Rural Extension Company (EMATER)/Salto do Lontra.

The variables listed to make feasible the analysis of the organizational and institutional environments participation in the strengthening of irrigation in the family agriculture of Salto do Lontra were: schooling of the smallholders, age, number of people in the property, income of the property, $\%$ of income destined for financial payment, irrigation system used, technical assistance, water quality control used in irrigation before and after system implantation, soil quality control before, difficulties to irrigate and irrigation benefits.

\subsection{Statistical Measures}

The data were tabulated and described by descriptive statistics, using the Excel software to generate the database, and from that, the main variables listed in the questionnaires and interviews were estimated.

For the analysis of the schooling, age, number of people in the property, income of the property and $\%$ of destined income to financing it was used the arithmetic means, denoted by: 
Where, $\mathrm{n}=\sum_{\mathrm{i}=1}^{\mathrm{k}} \mathrm{n}_{\mathrm{i}}$.

$$
\overline{\mathrm{x}}=\frac{\sum_{\mathrm{i}=1}^{\mathrm{k}} \mathrm{x}_{\mathrm{i}} \mathrm{n}_{\mathrm{i}}}{\mathrm{n}}
$$

To quantify qualitative data such as: irrigation system used, technical assistance, water quality control used in irrigation before and after system implantation, control of soil quality before, difficulties to irrigate and irrigation benefits were used relative frequency analyzes, representing its values percentage, denoted by:

$$
\mathrm{f}_{\mathrm{i}}=\frac{\mathrm{n}_{\mathrm{i}}}{\sum \mathrm{n}_{\mathrm{i}}}=\frac{\mathrm{n}_{\mathrm{i}}}{\mathrm{n}}
$$

Both the means and the frequencies were represented graphically during the analysis.

To complement the analysis, interviews were made with presidents of representative organizations of irrigating smallholder in that municipality to identify the actions carried out as well as the participation of the local irrigating smallholder. The description of these interviews is described descriptively.

\section{Results and Discussions}

\subsection{The Perception of the Institutional Environment by the Irrigating Smalholder of Salto do Lontra}

The rules imposed by the institutional environment can be observed in the set of laws, customs and traditions

that interfere directly in the competitive environment of the economic sectors. This is the normative side of economics and they are common to all agents, thus delimiting or expanding individual and collective actions. The organizations that are part of the economic process are the agents responsible for mitigating the negative impacts linked to both formal and informal rules, denoting the organizational environment that influences in a decisive way the sector coordination.

Among the most commonly used credit access programs for smalholder is the National Program for Strengthening Smallholder agriculture (Pronaf). This program presents several outcomes, such as Pronaf Financial and More Food. The Pronaf Financial was created to finance production which loans value up to $\mathrm{R} \$ 250.000$ per borrower or agricultural year, with interestrate ranging from $2.5 \%$ to $5.5 \%$ per year, depending on the activity. The payment term is from 1 to 3 years, depending on the activity developed (BCB, 2019).

Regarding Pronaf More food, this is intended for the expansion, renovation, machinery purchase and equipment, including irrigation. The loan amount can total $\mathrm{R} \$ 330.000 .00$ for smallholder each in an agricultural year. The interest on this subgroup of Pronaf varies from $2.5 \%$ to $5.5 \%$ depending on the destination of the financing. For the implementation of the irrigation systems, interest rates reach $2.5 \%$ per year for payment in up to 10 years, with the first three years of lack period (BCB, 2019). It is worth noting that in order to have access to Pronaf, the smallholder must comply the requirements established by the federal government.

This credit program is offered by several financial institutions at the local level, but those that stand out in Salto do Lontra are the credit unions. From the 35 smallholders interviewed, $65.71 \%$ have financing for their irrigation systems and their productive activities in the Cooperative System of Rural Credit with Solidarity Interaction (Cresol) and Cooperative Credit System (Sicredi). Added to the participation of those who have financing from cooperatives and public banks jointly, the number is even greater. Other $17.14 \%$ is in charge of the smallholders who have subsidized irrigation kits through extension projects. The most impressive is the dependence of smallholders on the financing, since only $5.71 \%$ of the farmers do not have any type of financing (Figure 2). 


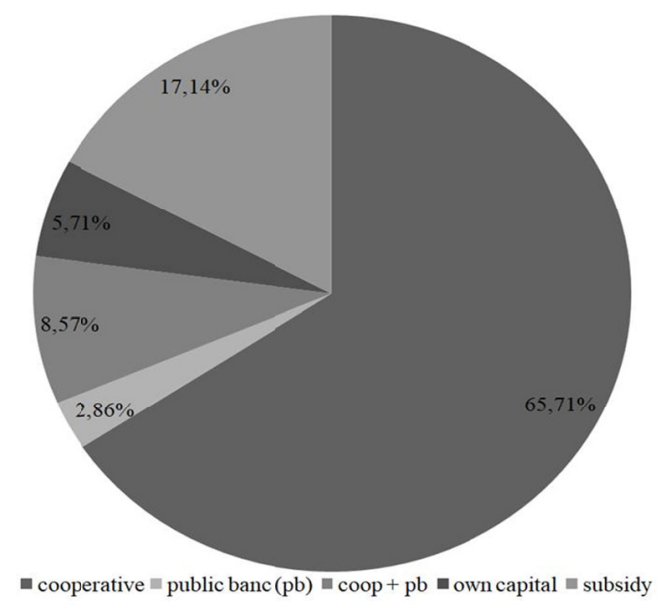

Figure 2. Participation of the financial institutions in the demand for credit by smallholder interviewed

It shows a large participation of the informal rules in the decision of these farmers, since many contributed to the founding of the mentioned cooperatives and $11 \%$ occupied positions of leadership in these institutions. This fact corroborates for greater acceptance and reliability on the part of the local producer, emphasizing the trust in companies that value the economic agent, inserting it in the management process.

It is not a habit of smallholder irrigating of Salto do Lontra searching for credit with cereal factories, suppliers of inputs, moneylenders or relatives. The interviewed assured that even the interest charged by federal programs being inadequate for the ownership profile, they still have lower interests if considering the credit of third parties.

However, one fact that contributes to the increasing difficulties for these irrigating smallholders is the proportion of income committed to financial institutions. From those interviewed, $37 \%$ have an average of $30 \%$ of their income committed to financing in an estimated eight-year payment period. About $46 \%$ have up to $20 \%$ of their income committed with financing with a term of 6 years for payment (Figure 3).

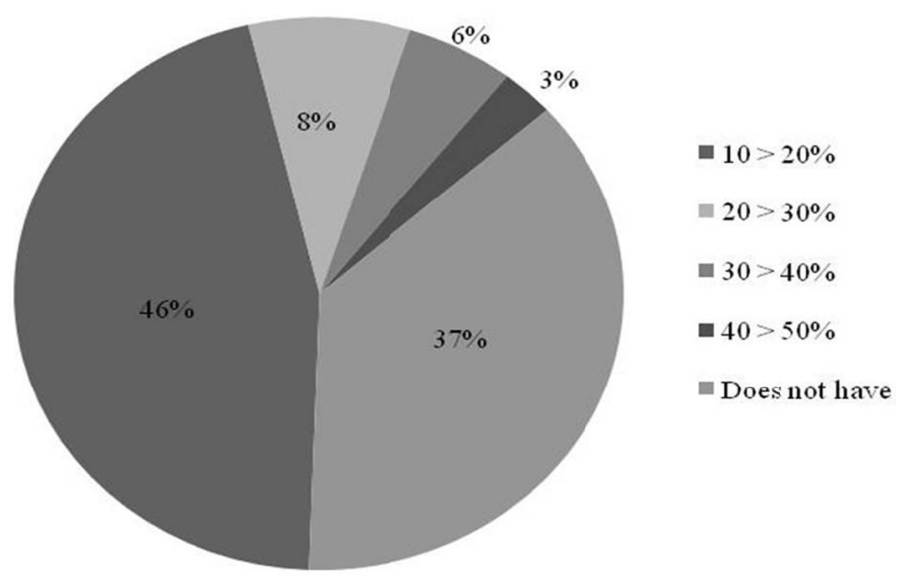

Figure 3. Percentage of property income destined to pay the financing

This group represents the technical producers, who invest in modern technologies to increase the productivity of the developed activities, wich includes new irrigation systems. During this time, it may be necessary to destine the financial payment to the implementation of different technologies, resulting in new loans, increasingly tying the smallholder who seeks to be competitive in the financial sector.

However, it is important to emphasize that the reality of the smallholder of Salto do Lontra has improved greatly with irrigation. If there is still dependence on the financial sector, it is lower than in periods prior to the use of the technology. Currently, the smallholder seeks the technification to conquer new market niches by increasing 
income in their activities (Figure 4). Most farmers interviewed have income between 10 and 20.000 reais, about $4615 \%$. An increase of $30 \%$ after the use of irrigation.

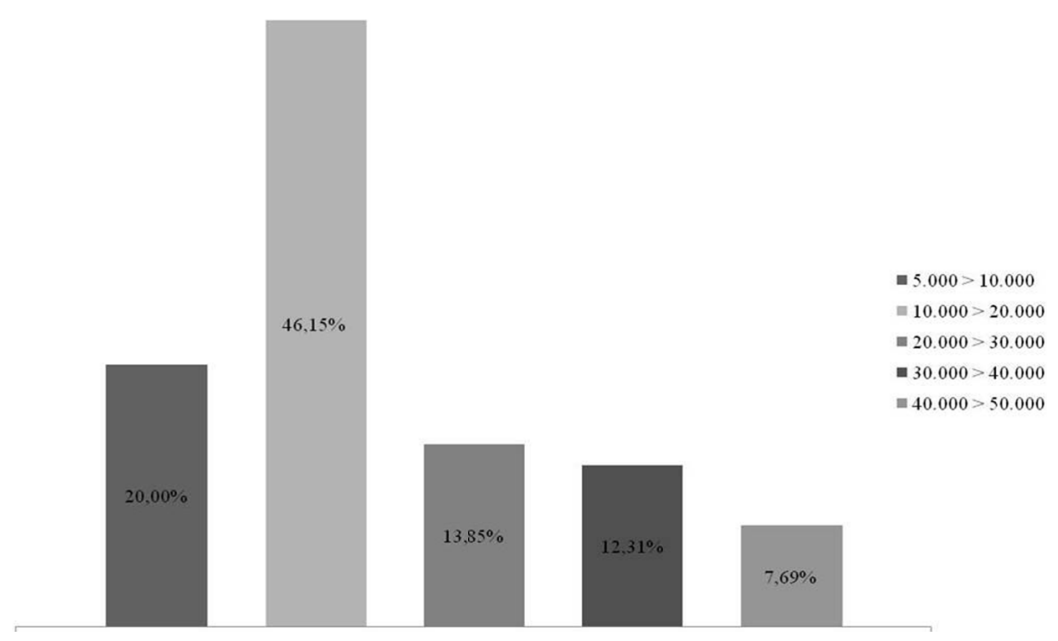

Figure 4. Income from properties with irrigation

On the other hand from the institutional perspective, another public policy that is used by the irrigating smallholder of Salto do Lontra focuses on the National Program to Support School Feeding (PNAE). It is a program managed by the National Education Fund that provides financial resources for both states and districts with the purpose of purchasing school meals from local smallholder (FNDE, 2019). This program contributes for the income of the family production to remain local, stimulating the perpetuation of the activities developed, as well as contributing to guarantee the sales of what is produced.

In Salto do Lontra, only two irrigating smallholders participate in this program, offering fruits and vegetables to local schools. Three other fruit and vegetable producers prefer to serve supermarkets in the district and neighboring towns since, the income is greater than that coming from PNAE. Even so, they are guaranteed on the purchase of their products. This scenario is positive for the irrigating smallholder who producesfruts and vegetables because there are a few producers in such activities. Thus, a high demand with a low supply entails prices that are reasonable for those who sell.

Another aspect of paramount importance for smallholder agriculture is tied to environmental laws. Being a social group that produces about $70 \%$ of the food internally consumed (IBGE, 2019), it is also a great agent that modifies the environment in which its activities are developed. As for the environmental laws aimed at the smallholder, the guidelines that conduct the implementation of irrigation systems are based on the National Irrigation Policy. The focus is on the adequate management of soil and water resources, integrating the activities irrigated with the surrounding environment (Brasil, 2006).

For the group of smallholders interviewed in Salto do Lontra, some questions related to irrigation technology are considered irrelevant. The Figure 5 represents the interviewed' answers, where $97.14 \%$ of the smallholders said they did not analyze the quality of the water used to irrigate. This attitude can influence the performance of the system as well as the quality of the final product. It is important to note that $62.86 \%$ did soil analysis before implanting the irrigation system. This is due to the fact that this variable is a requirement for the smallholder to have access to the credit for cost. However, 97.14\% did not perform the soil analysis after the irrigation system implantation, which is of paramount importance to provide moisture and correct soil density, influencing the productivity. Regarding the environmental concerns, $88.57 \%$ of the interwieveds consider of utmost importance. However, the actions for the environment are still lacking. There is control of the distribution of pesticides flasks, ciliary forest and care with the spring water. 


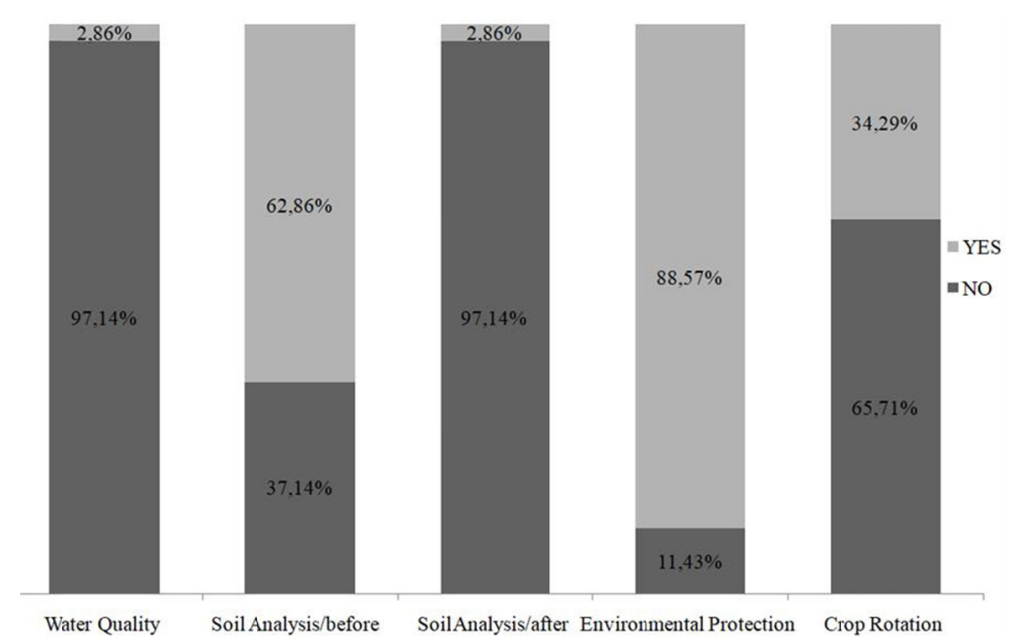

Figure 5. Participation of smallholder interviewed by Salto do Lontra-PR jump on environmental

Another important factor when considering the irrigation in smallholder agriculture under the institutional perspective is the granting of water. The use of water from springs, streams, rivers or lakes should be sought according to the National Water Agency when the amount used exceeds $1.8 \mathrm{~m}^{3}$ of water. If the volume does not reach this amount, the producer simply issues the Application for Independent Use of Water Grant (RUIO) and files with the state regulatory agency and the case of Parana, the Water Institute. This is the frequent action among the irrigating smallholder of Salto do Lontra, because they use a quantity of water inferior to the one foreseen in the law. For the emission of RUIO, they resort to the assistance of the Agriculture Department of the district, as well as the technicians of Emater.

This range of actions taken by the irrigating smallholder of Salto do Lontra, within the perspective of the institutional environment, shows the reality of this group against the formal and informal rules. The difficulties presented can be mitigated if there is a proposed organizational environment offering services that reduce the impacts of institutional norms.

\subsection{The Irrigating Smallholder Agriculture of Salto do Lontra From the Perspective of the Organizational Environment}

The organizational environment is composed of different groups of individuals, both public and private, with common goals. Their joint actions generate synergies, thus giving support to the competitiveness and consolidation of a sector. For the irrigating smallholder agriculture of Salto do Lontra, this environment becomes essential for the maintenance and stimulation of local irrigation.

The financial agents are essential elements of the organizational environment for the irrigating smallholder agriculture of Salto do Lontra. These organizations make public funding policies and such norms reach the smallholder for the purpose of inserting them into the credit market. The district has five financial agencies, which are public, private or cooperative. All the interviewed use the services of these agencies, without resorting to financial agents from neighboring districts. The discussion of the perception of smallholders regarding the actions developed by these financial organizations was detailed in the analysis of the institutional environment to give greater credibility as well as understanding to the national credit policy.

It is of great importance to emphasize the role of the Technical Assistance and Rural Extension Company-EMATER, located in Salto do Lontra since 2004. This organization is mainly focused on smallholder agriculture in the district, developing actions that contribute to strengthen the activities of the rural environment, such as: technical guidelines on dairy cattle, dairy, grains, vegetables, fruit and agribusiness. In addition, they assist the organization with the necessary documentation for the smallholder agriculture to access public policies such as Pronaf, Solidarity Tractor, Night Irrigation Program (NIP), Application for Independent Use of Water, Rural Housing, Paranaense Family, land regularization, land credit and the Soil and Water Management Program in Microbasins. It should be noted that the actions regarding the technical guidelines are continuous and the implementation of public policies is sporadic, according to the demand of the smalholders.

The demand for services offered by Emater Salto do Lontra is high. However, the number of employees is insufficient, counting today with two extension technicians to serve 1.410 properties of smallholder. This 
scenario reflects the dissatisfaction of $80 \%$ of the irrigating smallholder interviewed regarding the service provided by Emater technicians. For those farmers, technicians are present only in the act of convincing them to implant the irrigation method. In the period of operation, they are not supported to identify whether the system is suitable for the activity or it is responding efficiently. This locally observed scenario reflects a continuity at a national level, which indicates the need for a larger labor force focused on the demands of smallholder agriculture (Souza et al., 2018).

For Emater technicians, the greatest difficulties to either maintain or encourage the number of irrigating smallholder in the district is the lack of knowledge of the producer regarding the time of system used and its benefits, as well as the quantity and quality of water to irrigate Another highlighted factor is the lack of technical assistance from the companies that supply the irrigation equipment, merely making themselves present in the sale, but little contributing at a later time.

As for the partnerships, Emater is constantly integrated into events or programs of the department of agriculture, trade unions, financial agents, universities of the region, private companies, Iapar and Embrapa. This interaction between the organizations that support smallholder contributes to the development of projects that will meet the needs of Salto do Lontra smallholders.

However, some observations are relevant. Emater's limited labor force significantly reduces the scope of the proposed actions, often not reaching the knowledge of these economic agents. Also, have the lack of initiative of the irrigating smallholders to seek information and knowledge through participation in events and lectures. In many cases, the lack of commitment of smallholders, unaware of the real importance of irrigation for their properties, the impact that water stress can cause to the plant ends up hampering the actions of the collaborative organizations. A scenario that is influenced by the education level of the smallholder of municipality (Figure 6), where $46 \%$ has only incomplete the elementary school and only $6 \%$ with the complete higher education.

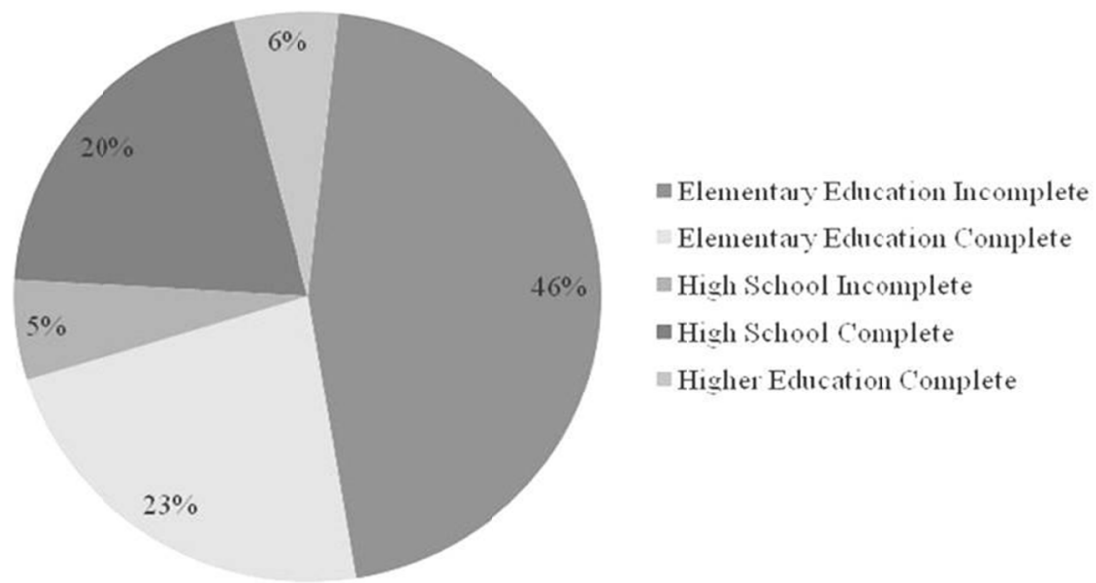

Figure 6. Educational level

The low education and qualification of the irrigation smallholder of Salto do Lontra, reflects a national panorama. It is a cultural process, where the wait for assistance and, foreign aid still thrives in the sector, however that can be changed with a greater insertion of these organizations in the producer reality.

Another representative organization of smallholder is the Union of Rural Workers of Salto do Lontra. This organization aims to help the smallholder, mainly in the legal proceedings. As far as irrigation is concerned, there is no contribution. The demand is to obtain maternity aid from smalholder, pensions and sickness aid. Some projects are designed to help the protection of springs and the bureaucratic part of the Minha Casa Minha Vida program. Currently, the union has about 1.000 members, but only 300 pay the annuity. For years the union has not offered any courses or lectures aimed at the qualification of the rural man due to the low demand, making events unfeasible. Age influences the low demand for qualification. Most of the interviewees are between 56 and 65 years old (Figure 7), a period in which the productivity of the workforce is lower. 


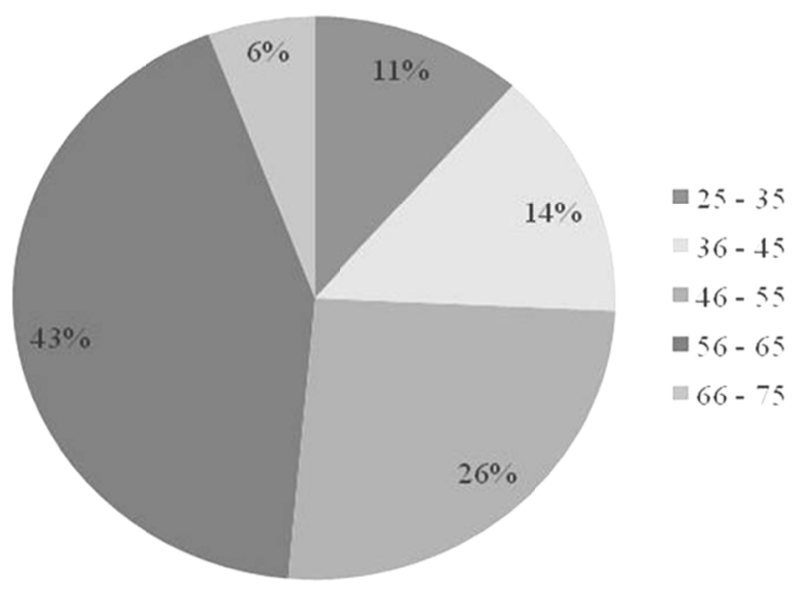

Figue 7. The interviewees' age

The reduction in the number of young people on rural properties is one of the factors that most impacts the lack of stimulation of these producers. The average is two children per family, representing $37 \%$ of the farmers interviewed (Figure 7). These young people, for the most part, are looking for better conditions in the cities and little by little heavy duty discourages owners from continuing with irrigation systems.

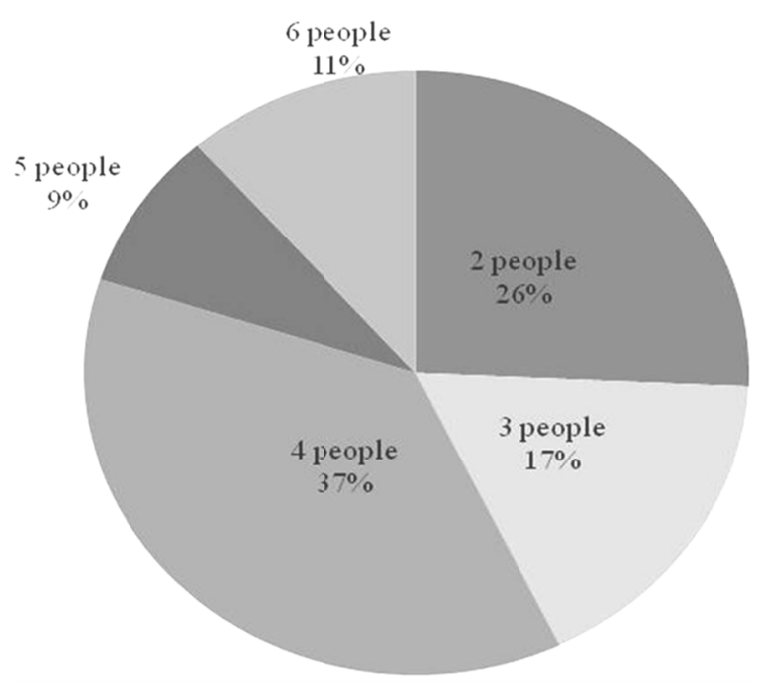

Figure 7. Number of people residing and working on the property

The lack of commitment of smallholders to the organization that represents them, as well as the lack of interest of young people to participate of events provided by the organization are pointed as pillars of the weakening of the organization at a local level.

This fact refers to the closure of the Rural Patronal Union, which closed its activities in the year 2015 due to political issues and low participation of farmers. In conjunction with the analysis it can be quoted the lack of Senai with its apprenticeship courses at the agricultural implements level, as well as the Sebrae with the rural youth courses, such as the rural entrepreneur. These organizations are located in neighboring districts, but their interrelationships with the irrigating smallholder of Salto do Lontra do not occur.

The Department of Agriculture also represents an extremely important organization for the family agriculture of Salto do Lontra, especially the irrigated one. The Gross National Product (GNP) of the district is formed, for the most part, by the activities of family agriculture. Thus, the public power seeks to assist farmers from bureaucratic issues to technical issues. 
They contribute to the elaboration of projects that aim to increase the productive capacity of family property, such as Pronaf Custeio. Also, they offer technical support prioritizing the milk production chain, which accounts for $90 \%$ of the activities developed by local smallholder agriculture. The district produces about 1.5 million liters of milk monthly, corroborating for its strong regionally representation (Deral, 2018).

The public sector contributes to this scenario through the Artificial Insemination Program (PIA), supported by the state government. The district, through the Department of Agriculture of Salto do Lontra provides the nitrogen cylinders for the producers to store the semen of the animals purchased. Aiming at genetic improvement, the department's technicians give courses to assist the smallholder in the best choice of breed to be inseminated to obtain the expected results, such as increased production, herd management, reduction of labor accidents and product quality last. The demand is high and producers are interested in these actions and prioritize them, because they know that the higher the knowledge, the higher the income generated from the property.

Another program offered at the local level is the Machine on Ownership, where the producer is entitled to 10 hours a year paying $50 \%$ less than the market value. The irrigating smallholder benefits from these machines to make the drainage of the irrigated area, since the majority uses irrigation for pastures. Also, the public power assists with the topographic survey and contour lines in the inter-harvest season.

It is worth emphasizing the relevance given to the partnerships among several organizations so that many projects solidify and strengthen themselves locally. Among the partners, the National Rural Learning Service (SENAR), Banco do Brasil (BB), Rural Workers' Union, Emater and credit cooperatives are mentioned.

The local Associations constitute an extremely important organization for the irrigating smallholder of Salto do Lontra. Each community has an association that receives agricultural machinery and equipment via state government funds, to be used in the producers properties. Each farmer rents the machines he needs at a price $50 \%$ lower than the market. The amount charged is for the maintenance of the machines. The communities organization contributes to the reduced production cost, helping the smallholder to access the technologies at a compatible price with their production capacity. These actions allow the smallholder to make new investments in the quality and productivity of their activities.

This scenario corroborates to show that the irrigating smallholder perceives in the organizational actions a strong alternative to reduce costs and, consequently, increase the gains of the developed activities in the property. This shows that he feels inserted in the construction of activities that strengthens his participation as a rural producer in the competitive market. In order for irrigation to be perceived as relevant to rural properties, emphasis should be placed on the dissemination of knowledge in rural areas. Many realize that irrigation is essential, but few know about the system's operation, the need to identify whether uniformity is correct, whether the system is suitable for its region and activity, whether the form of handling is adequate to ensure longer life usefulness of the used system. Such information should be a constant in these farmers, not just randomly. Let him realize that irrigation is part of the prosperity of his primary activity, or that it provides gains in secondary activities. There is a lack of commitment from the organizations to support and stimulate actions aimed at the use of irrigation locally, often for lack of knowledge of the sector's representative bodies.

It is also important to highlight the participation of the only company that provides irrigation systems in the region. Its core activity is focused on the equipment Sales, so that it clarifies the producer as to the area, water need, the existing technologies and the type that best adapts to the site that will be irrigated. However, they do not have an after-sales service regarding the training of the producer to better use the chosen system, as well as to assist in basic problems such as sprinkler clogging, leaks or equipment exchange. The maintenance service is offered under the producer requests, but with an additional cost.

One of the great pillars of the organizational environment are the universities. Through research and extension projects the universities can join the community. This took place in Salto do Lontra in 2008, with projects of professors from the Agricultural Engineering course of the State University of West Parana (UNIOESTE) and is perpetuated to this day with the participation of other universities, such as the Federal Technological University of Parana (UTFPR).

With the partnership of Emater was presented to the smallholder the tecnology irrigation. Aiming to assist the producer in making decisions and clarifications regarding to the use of technology, benefits and difficulties. At the outset, drip irrigation kits were purchased through an extension project sent to MCT/CNPQ/CT-HIDRO.

The first actions were to pass on the information needed by smallholder on irrigation technology, involving exposure of the method used, as well as the importance of soil and water quality for the technology property 
effectiveness. During the project period the smallholder was accompanied by professors and students of doctorate, masters and graduation. Emater was responsible for the technical assistance to smallholder.

Due to the excessive manual labor with the drip system, many farmers poor health, change in activity and the fact that there is a low a succession on these properties, $25 \%$ of the interviewed producers who received the irrigation subsidy have given up using the technology. On the other hand, those producers that irrigation proved to be important and the above conditions proved to be contrary, began to use more efficient systems, as well as, extended the irrigated area.

Among the smallholder interviewed, the highest number of irrigated properties is in the group with land from 5 to less than 10 hectares $(5>10)$, with $51.43 \%$, representing about 36.57 irrigated hectares out of a total of 132.38 hectares. However, this group represents $33.3 \%$ of smallholder who gave up irrigation, a total of 43.62 hectares were no longer irrigated (Figure 8). This is because they have smaller amounts of land, lower production diversification, and lower educational levels. This time for this group of irrigating smallholder, the return on investment in irrigation technology varies between 2 and 6 years, with $30.3 \%$ being able to pay in 4 years.

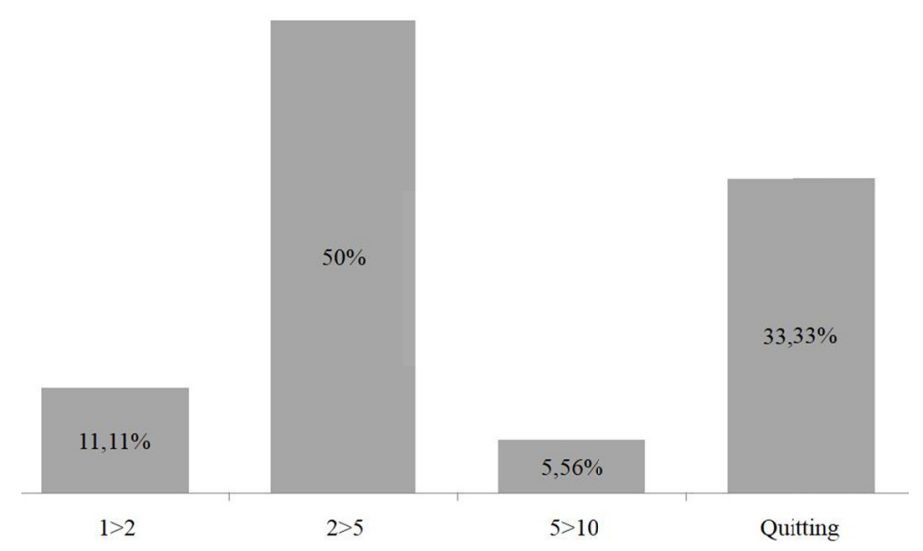

Figure 8. Total irrigated area for the group that has 5 to less than 10 hectares

Irrigating smallholder with an area of less than 50 hectares $(10>50)$ irrigate $53.33 \%$ of the total land. There is no representation of irrigators with an area of less than 2 hectares. This group is able to diversify activities, produce in scale, and have a higher educational and technological level (Figure 9). The return time of the investment with irrigation prevails the same, from 2 to 6 years. Thus, the size of the irrigated area does not interfere with the system payment time.

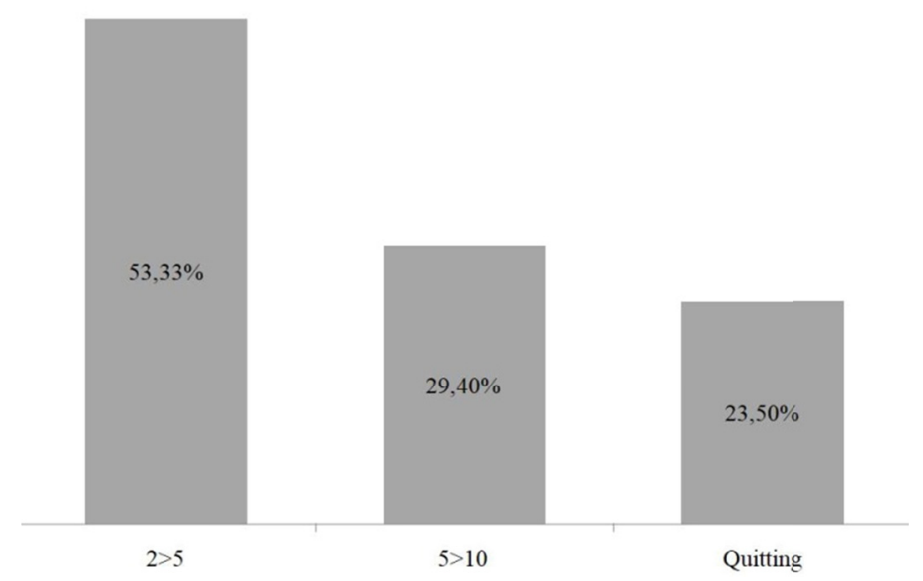

Figure 9. Total irrigated area for the group that has 10 to less than 50 hectares 
The most used system is the sprinkler, with $87 \%$, depicting the national scenario (ANA, 2017). It is a system that, according to the interviewed, offers high efficiency, low management and costs compatible with the local reality. The satisfaction with the irrigation use led to a $92 \%$ increase in the irrigated area of this group of smalholder, a scenario close to that identified by the Agricultural and Livestock Census 2017, which showed a $100 \%$ increase in irrigated area of the same size and same type of interviewed system (sprinkling and dripping) in the district in the last 10 years.

This demonstrates that the universities are disseminators of irrigation technology in Salto do Lontra. The approach of knowledge, the developed work valorization by this group of producers and the respect with which they were treated created positive synergies among the agents, which is intrinsic to the organizations that seek common goals and strengthen the bonds between the economic agents. However, these same farmers who remained with irrigation note that there is a greater need for services and support provided by universities.

A strong, consolidated organizational environment, in which individuals work to strengthen a sector induces an increase in competitiveness of economic agents and, consequently, of other organizations that eventually form a productive chain. The organizational background interconnected with the environment institutional actions provides greater competitiveness, maturity, information and coping capacity in difficulty times. This scenario may contribute to the smallholder of Salto do Lontra, identifying the best form of coordination and emphasizing the collective effort of this productive category.

\section{Conclusion}

Irrigation technology is an alternative for the sustainability of smallholder agriculture in the municipality of Salto do Lontra, southwest of Parana. However, the use of this technology requires knowledge, information, producer qualification and adequate technical assistance, in order to keep the system functioning with total efficiency.

As a result, the present study analyzed the institutional and organizational environments participation of the district of Salto do Lontra, southwest of Parana, in order to identify the actions developed by these entities in favor of the implantation and perpetuation of irrigation locally. A total of 35 questionnaires were applied to irrigating smallholder, realizing the difficulties and benefits that the technology has brought them since the implementation of the project by the Unioeste/Cascavel Agricultural Engineering course in 2008.

The institutional environment was very prone to the strengthening of this producers group, offering a solid base of financial agents locally, which help in the public policies accessibility promoted by the federal, state and municipal governments, emphasizing the formal rules of this environment. By the informal rules, these farmers show that customs and traditions prevail locally. The greater demand for credit occurs in credit cooperatives, organizations that many smallholders helped to found, exercising managerial positions. This proximity helps farmers feel more confident and appreciates their role as food producers and regional development promoters.

However, what worries is the degree of indebtedness of this smallholder, who has up to $30 \%$ of his income committed in $37 \%$ of the properties interviewed and $46 \%$ of them have up to $20 \%$ of their income compromised. However, during the payment period, new investments are needed in the property, further tying the smallholder with the financial system.

With regard to the organizational environment, it was possible to perceive that the universities were an incentive and propeller of the irrigation technology in the municipality, favoring the increase of the irrigated area and the number of establishments with irrigation, going from 62 in 2004 to 103 in 2012. With the professors and academics help, farmers learned about irrigation and were willing to implement it on their properties in 2008 . However, with insufficient financial incentives from the federal and state governments to continue the extension project after 2012, one can not continue research and identify the responses that irrigation could bring in social and economic terms.

The reflex was felt in the field, where the difficulty in maintaining the equipment, the impossibility of hiring labor, the health problems and the activity change contributed for about $40 \%$ of the smallholder to give up of the irrigation. Of the group interviewed, $25 \%$ left irrigation recently.

This reality denotes a disruption of the organizational environment supporting the irrigating family agriculture. There is a need for an efficient coordination of the involved agents with this sector in Salto do Lontra. Support and stimulate joint actions, bring information in a coherent way and according to the local reality, generate positive externalities and contribute to the agents feel that they belong to the locality, are the challenges that must be overcome in order to have an active irrigation smallholder agriculture and strengthened at the regional level. 


\section{References}

ANA (Agência Nacional de Águas). (2017). Atlas Irrigação: Uso da água na agricultura irrigada, DF. Agência Nacional de Águas, Brazil. Retrieved from http://www.ana.gov.br

BCB (Banco Central do Brasil). (2019). Retrieved from https://www.bcb.gov.br

Beekman, W., Veldwisch, G. J., \& Bolding, A. (2014). Identifying the potential for irrigation development in Mozambique: Capitalizing on the drivers behind farmer-led irrigation expansio. Physics and Chemistry of the Earth, Parts A/B/C, 54-63. https://doi.org/10.1016/j.pce.2014.10.002

Brasil. (2006). Lei n. 11346, de 15 de Setembro de 2006. Creates the national system of food and nutrition security-SISAN, with a view to ensuring the human right to adequate food and other measures. Official Gazette of the Federative Republic of Brazil, Executive Branch, Brasília, DF.

Caviglionli, J. H., Kiihl, L. R. B., Caramori, P. H., Oliveira, D. de., Galdino, J., Borrozino, E., ... Pugsley, L. (2002). Cartas climáticas do Paraná. Instituto Agronômico do Paraná, Londrina, PR. Retrieved from https://www.iapar.br

Cunha, K. C., \& Rocha, R. V. da. (2015). Automation in the irrigation process in smallholder agriculture with Arduino platform. Revista Eletrônica Competências Digitais para Agricultura Familiar, 1, 15-27.

DERAL (Department of Rural Economy). (2018). Retrieved from https//www.agricultura.pr.gov.br

FAO. (2014). The State of food and agriculture 2014: Innovation in smallholder. Retrieved from https//www.fao.org

Giordano, M., \& Fraiture, C. de. (2014). Small private irrigation: Enhancing benefits and managing trade-offs. Agricultural Water Management, 167-174. https://doi.org/10.1016/j.agwat.2013.07.005

Hagos, F., \& Mamo, K. (2014). Financial viability groundwater irrigation and its impacto $\mathrm{n}$ livelihoods of smallholder farmers: The case of eastern Ethiopia. Water Resources and Economics, 55-65. https://doi.org/ 10.1016/j.wre.2014.08.001

Brazilian Institute of Geography and Statistics. (1997). Smallholder Agriculture-Brazil, Major Regions and Federative Units, Agricultural Census 1995/86. Retrieved from http:// www.ibge.gov.br

Brazilian Institute of Geography and Statistics. (2007). Smallholder Agriculture-Brazil, Major Regions and Federative Units, Agricultural Census 2006. Retrieved from http:// www.ibge.gov.br

Brazilian Institute of Geography and Statistics. (2018). Smallholder Agriculture-Brazil, Major Regions and Federative Units, Agricultural Census 2017. Retrieved from http:// www.ibge.gov.br

FNDE (National Education Fund). (2019). Retrieved from http:// www.fnde.gov.br

IPARDES (Paranaense Institute of Economic and Social Development). (2014). Districts and regions. Retrieved from http://www.ipardes.gov.br

IPARDES (Paranaense Institute of Economic and Social Development). (2017). Districts and regions. Retrieved from http://www.ipardes.gov.br

Khor, L. Y., \& Feike, T. (2017). Economic sustainability of irrigation practices in arid cotton production. Water Resources and Economics, 20, 40-52 https://doi.org/10.1016/j.wre.2017.10.004

Kooij, S., Kuper, M., Fraiture, C. M. S. de, Lankford, B., \& Zwarteveen, M. Z. (2017). Re-allocatting yet-to-saved water in irrigation modernization projects: The case of the Bittit irrigation system, Morocco (pp. 68-84). Drip Irrigation for Agriculture: Untold Stories of Efficiency, Innovation and Development, NY. https://doi.org/10.4324/9781315537146-5

Loiola, M., \& Souza, F. de. (2001) Estatísticas sobre irrigação no Brasil segundo o Censo Agropecuário 1995-1996. Revista Brasileira de Engenharia Agrícola e Ambiental, 5, 171-180. https://doi.org/10.1590/ S1415-43662001000100033

MDA (Ministério de Desenvolvimento Agrário). (2015). Retrieved from http://www.mda.gov.br/sitemda/ noticias/mais-irriga\% $\%$ 3\%A7\%C3\%A3o-para-agricultura-familiar-no-pa\%C3\%ADs

Mwangi, J. K., \& Crewettb, W. (2018). The impacto f irrigation on small-scale African indigenous vegetable growers market acess in Peri-urban Kenya. Agricultural Water Management, 212, 295-305. https://doi.org/ 10.1016/j.agwat.2018.06.036

SEAB (Secretaria de Agricultura e Abastecimento). (2018). Retrieved from http://www.agricultura.pr.gov.br 
Souza, P. M., Formazier, A., Silva, A. M. da, \& Ponciano, N. J. (2018). Tecnology in Brazilian agriculture: An analysis of the regional inequalities for the family end non-family sectors. Revista Econômica do Nordeste, 49, 147-169.

Tijani, M. N., Obayelu, A. E., Sobowale, A., \& Olatunji, A. S. (2014). Welfare analysis of smallholder farmers by irrigation systems and factors affecting their production outputsin Nigeria. Sustainability of Water Quality and Ecology, 90-100. https://doi.org/10.1016/j.swaqe.2014.12.002

\section{Copyrights}

Copyright for this article is retained by the author(s), with first publication rights granted to the journal.

This is an open-access article distributed under the terms and conditions of the Creative Commons Attribution license (http://creativecommons.org/licenses/by/4.0/). 